\title{
Strategic public policy around population thresholds
}

Citation for published version (APA):

de Witte, K., Geys, B., \& Schonhage, N. L. (2018). Strategic public policy around population thresholds. Journal of Urban Economics, 106, 46-58. https://doi.org/10.1016/j.jue.2018.06.001

Document status and date:

Published: 01/07/2018

DOI:

10.1016/j.jue.2018.06.001

Document Version:

Publisher's PDF, also known as Version of record

Document license:

Taverne

Please check the document version of this publication:

- A submitted manuscript is the version of the article upon submission and before peer-review. There can be important differences between the submitted version and the official published version of record.

People interested in the research are advised to contact the author for the final version of the publication, or visit the DOI to the publisher's website.

- The final author version and the galley proof are versions of the publication after peer review.

- The final published version features the final layout of the paper including the volume, issue and page numbers.

Link to publication

\footnotetext{
General rights rights.

- You may freely distribute the URL identifying the publication in the public portal. please follow below link for the End User Agreement:

www.umlib.nl/taverne-license

Take down policy

If you believe that this document breaches copyright please contact us at:

repository@maastrichtuniversity.nl

providing details and we will investigate your claim.
}

Copyright and moral rights for the publications made accessible in the public portal are retained by the authors and/or other copyright owners and it is a condition of accessing publications that users recognise and abide by the legal requirements associated with these

- Users may download and print one copy of any publication from the public portal for the purpose of private study or research.

- You may not further distribute the material or use it for any profit-making activity or commercial gain

If the publication is distributed under the terms of Article $25 \mathrm{fa}$ of the Dutch Copyright Act, indicated by the "Taverne" license above, 


\title{
Strategic public policy around population thresholds ${ }^{\text {th }}$
}

\author{
Kristof De Witte $^{\mathrm{a}, \mathrm{b}}$, Benny Geys ${ }^{\mathrm{c}, *}$, Nanna Lauritz Schönhage ${ }^{\mathrm{d}}$ \\ ${ }^{a}$ Top Institute for Evidence Based Education Research, Maastricht University, Kapoenstraat 2, 6200 MD Maastricht, The Netherlands \\ ${ }^{\mathrm{b}}$ Leuven Economics of Education Research, University of Leuven (KU Leuven), Naamsestraat 69, Leuven B-3000, Belgium \\ ${ }^{\mathrm{c}}$ Norwegian Business School (BI), Nydalsveien 37, Oslo N-0442, Norway \\ ${ }^{\mathrm{d}}$ Department of Applied Economics (APEC), Vrije Universiteit Brussel, Pleinlaan 2, 1050 Brussel, Belgium
}

\section{A R T I C L E I N F O}

\section{JEL-classification:}

$\mathrm{H} 70$

$\mathrm{J} 18$

R23

R38

Keywords:

Rent-seeking

Political agency

Building permits

Fiscal policy

\begin{abstract}
A B S T R A C T
Political economists have long maintained that politicians respond to both (re-)election and financial incentives. This article contributes to the latter literature by analysing whether, when and how local office-holders respond to the economic incentives embedded in exogenously imposed population thresholds leading to an increased number and remuneration of local politicians. Building on insights from the urban economics and public finance literatures, we argue that local politicians may strategically adjust fiscal and housing policies to stimulate inmigration when approaching a population threshold where their remuneration increases. Using data from all 589 Belgian municipalities over the period 1977-2016, our results confirm that approaching important population thresholds causes lower local tax rates and the granting of additional building permits (particularly for apartments). These policy changes occur early in the election cycle and, at least for housing policy, are restricted to incumbent mayors themselves expecting to benefit from crossing the population threshold.
\end{abstract}

\section{Introduction}

The remuneration of local government officials (i.e. mayors, aldermen and councillors) often increases at specific population thresholds. This is the case in, for instance, Belgium (more details below), Brazil (Ferraz and Finan, 2011a), Germany (Arnold and Freier, 2015), Italy (Gagliarducci and Nannicini, 2013), Romania (Klašnja, 2015), and the US (Hopkins, 2011). Since these thresholds are typically institutionalised in a legal framework set by a higher-level government, they are exogenous to local decision-making. Consequently, they can offer an interesting environment to compare social, political and economic outcomes in jurisdictions just above and below population thresholds determining a change in local political institutions. ${ }^{1}$ From a political economics perspective, however, the highly institutionalised and predictable nature of increases in politicians' remuneration at specific population thresholds might also have less favourable implications. The reason is that money matters, also to politicians. Several studies indeed highlight that politicians' remuneration plays a key role in candidate self-selection as well as decision-making once elected (Besley, 2004; Messner and Polborn, 2004; Ferraz and Finan, 2011a; Kotakorpi and Poutvaara, 2011; Gagliarducci and Nannicini, 2013; Cerina and Deidda, 2017). Since local politicians - just like most of us - may be assumed to have a positive marginal utility of money, they might have a personal, economic incentive to locate their municipality on the desired side of a population threshold implying higher remuneration. ${ }^{2}$

Consistent with this argument, Eggers et al. (2018) uncover evidence of local jurisdictions bunching on the better-remunerated side of

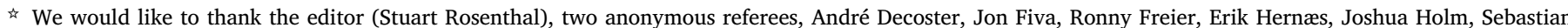

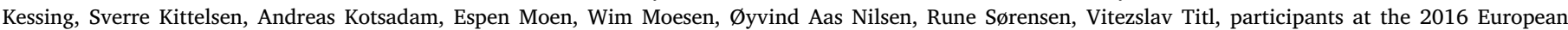

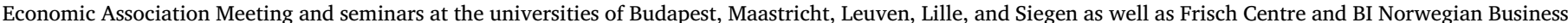

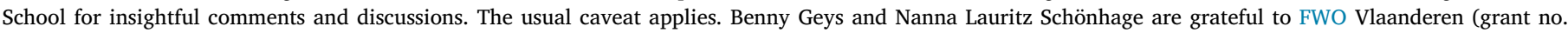
G000218N) for financial support.

* Corresponding author.

E-mail addresses: k.dewitte@maastrichtuniversity.nl, kristof.dewitte@kuleuven.be (K. De Witte), Benny.Geys@bi.no (B. Geys).

1 Examples of such regression discontinuity (RD) designs use data from, for instance, Brazil (Fujiwara, 2011; Brollo et al., 2013), France (Eggers, 2015), Germany

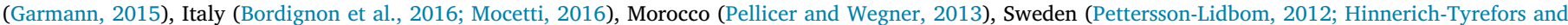
Pettersson-Lidbom, 2014) and the United States (Duggan et al., 2016).

2 As noted by Imbens and Lemieux (2008) and Urquiola and Verhoogen (2009), the inferences drawn from regression discontinuity (RD) designs using population

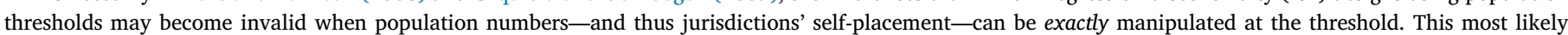
would require outright manipulation of population figures (Litschig, 2012; Foremny et al., 2017). 
relevant population threshold(s) in France, Italy and Germany. Yet, while Eggers et al. (2018) focus on what empirical researchers can do to avoid biased inferences due to such bunching, they do not study nor discuss the underlying mechanisms and temporal effects. These are at the heart of the present article. Our main contribution lies in assessing how and when - in the absence of outright manipulation (Litschig, 2012; Foremny et al., 2017)—local governments might influence population figures such as to locate themselves on the desired side of population thresholds. Building on insights from the urban economics and public finance literatures, our empirical focus thereby concerns local housing and fiscal policies. Although such policies are unlikely to precisely determine municipalities' position immediately around the threshold, they can have a non-negligible impact on local population developments and help municipalities reach the desired side of the threshold. ${ }^{3}$ For instance, the tax and yardstick competition literatures argue that fiscal policy can be used to attract firms and families (Wilson, 1986; Zodrow and Mieszkowski, 1986; Bordignon et al., 2003; Buettner, 2003; Geys and Osterloh, 2013). Likewise, housing policy and spatial planning decisions - such as land use regulation - have been shown to affect house prices and local population developments (Rose, 1989; Quigley et al., 2004; Glaeser and Ward, 2009; Kok et al., 2014). Furthermore, since the relevant population count is often recorded at specific points in time (e.g., an election year), manipulations of such policies are most likely timed with these 'deadlines' in mind.

Using data from all 589 Belgian municipalities over the period 19772016, our main findings can be summarized as follows. First, we find limited evidence of bunching around important population thresholds using traditionally employed density tests (McCrary, 2008). Yet, despite the absence of a clear structural break in the density at the thresholds, we do observe a strong upward trend in the density around the thresholds. This suggests that local administrations may not be able to finetune their placement just right of relevant thresholds, but can-and ostensibly do-influence their general position on the right side of these thresholds. Second, housing and fiscal policy - through their potential to stimulate in-migration (see above) ${ }^{4}$ - act as important mechanisms to achieve this aim. More specifically, municipalities close to a population threshold lower their property and income tax rates, and approve more building permits for residential housing. The effect on building permits for apartments is particularly strong, which reflects that apartment buildings allow more rapid short-term population growth relative to one-family houses. Third, we provide some evidence that municipalities close to a population threshold strategically time their housing and fiscal policy decisions. Since January 1 of an election year acts as a 'deadline' for recording the relevant population count since 2001, policy shifts during this post-2001 period (though not before 2001 when every year was a 'deadline') appear located early in the six-year election cycle to account for the time-lag in public responses to policy changes. Finally, we observe that strategic shifts in public policies are, at least for housing policy, only implemented when the incumbent mayor expects to benefit from crossing the population threshold by returning to power after the next election-which is when her personal economic incentive to pass a population threshold is strongest.

\footnotetext{
${ }^{3}$ Note that this is conceptually similar to re-election motivated politicians providing increased effort and changing public policies prior to elections in order to boost their electoral odds (see, for instance, Kubik and Moran, 2003; Shi and Svensson, 2006; Foremny and Riedel, 2014; Rohlfs et al., 2015).

${ }^{4}$ Clearly, cross-municipal migration is most likely among small municipalities in close proximity to each other. From this perspective, it is important to observe that Belgium is a small country ( $30528 \mathrm{~km}^{2}$; compared to roughly 10 million $\mathrm{km}^{2}$ for the US) where the average municipality has circa 19000 inhabitants and covers about $52.5 \mathrm{~km}^{2}$. On average, you can reach 27 (136) other municipalities within a straight-line $20 \mathrm{~km}(50 \mathrm{~km})$ radius of any given municipality. Moreover, official statistics indicate that internal migration within Belgium (from one municipality to another) equals approximately $4-5 \%$ of the population on an annual basis over the period 1991-2014.
}

\section{Institutional framework and data}

\subsection{Population thresholds in Belgium}

Belgian municipalities are governed through a parliamentary system with a legislative branch (the local council) and executive branch (the College of Mayor and Aldermen). Municipal elections take place on the second Sunday of October under a fixed electoral cycle of six years, whereby eligible citizens cast their ballot to elect local councillors using a system of Proportional Representation. The composition of the College of Mayor and Aldermen is subsequently determined by the party or parties holding a majority position in the council. These parties decide upon, and formally appoint by majority vote, the mayor and aldermen, which are exclusively selected from their councillors. There are no term limits for councillors, aldermen nor the mayor.

Both the size of the council (ranging between 7 and 55 councillors) and the College (ranging between 2 and 10 aldermen, plus the mayor) are determined by the municipality's number of inhabitants on January 1 of the most recent election year. As illustrated in the first two columns of Table 1, there are 24 (8) population thresholds at which the size of the council (College) increases. Similarly, the remuneration of the mayor is a function of the number of inhabitants. ${ }^{5}$ Prior to 2001, changes in population size would translate into mayoral remuneration on an annual basis, but since 2001 wages are determined using the population count on January 1 of the most recent election year (such that mayor wages remain fixed throughout the legislative term). ${ }^{6}$ Table 1 indicates the main population thresholds where the remuneration of the mayor and aldermen increases, and how the employed thresholds have developed over time. For the thresholds where the large majority of our observations is located (i.e. 5000 to 20,000 inhabitants), the mayor's change in remuneration generally reflects an increase of approximately $2 \%$ in the earlier part of our time period and more extensive increases of $6 \%$ to $19 \%$ in the later part of our time period. This can be substantively meaningful also in absolute terms (for a more detailed example at the 20,000-inhabitant threshold, see Section 4.3 below).

In Table 1, 17 population thresholds are in boldface. These are thresholds at which both the number of local councillors and the remuneration of mayor and aldermen increases at least during some years of our sample period. We focus on these thresholds for two reasons. First, the pecuniary incentives of mayor and aldermen at these thresholds are aligned with the incentives of all local political parties, since an increase in the number of councillors improves parties' probability to gain at least some seats under a proportional electoral system (Taagepera and Shugart, 1989; Lijphart, 1999). Hence, the motivation of all local politicians to influence population figures is maximised at this subset of population thresholds. Second, and consistent with the previous point, the results in Eggers et al. (2018: 225) indicate that the largest bunching effects are generally found "at thresholds where both council size and salary change". As such, these thresholds represent a best-case scenario to analyse the mechanisms underlying such bunching.

Municipal population sizes cross one of these 17 population thresholds relatively frequently. In total, we observe 366 threshold crossings in our period of observation, which in the vast majority of cases

\footnotetext{
5 We could find no evidence in national and regional legislation for the use of population-based thresholds for other local policies. The only exception relates to a signature requirement for organizing local referenda (Arnold and Freier, 2015), which increases at 15000 and 30000 inhabitants. As such referenda are uncommon (only 11 cases in more than 20 years) and always non-binding, this is unlikely to influence our findings.

6 The wage of the aldermen is linked to that of the mayor, and thus by construction increases at the same population thresholds. Local councillors do not receive a wage in Belgium, but are generally paid a fixed amount for every council meeting they attend. This attendance fee is determined by the local council subject to a simple majority vote (up to a legal maximum), and is therefore not linked to specific population thresholds.
} 
Table 1

Important population thresholds for Belgian municipalities.

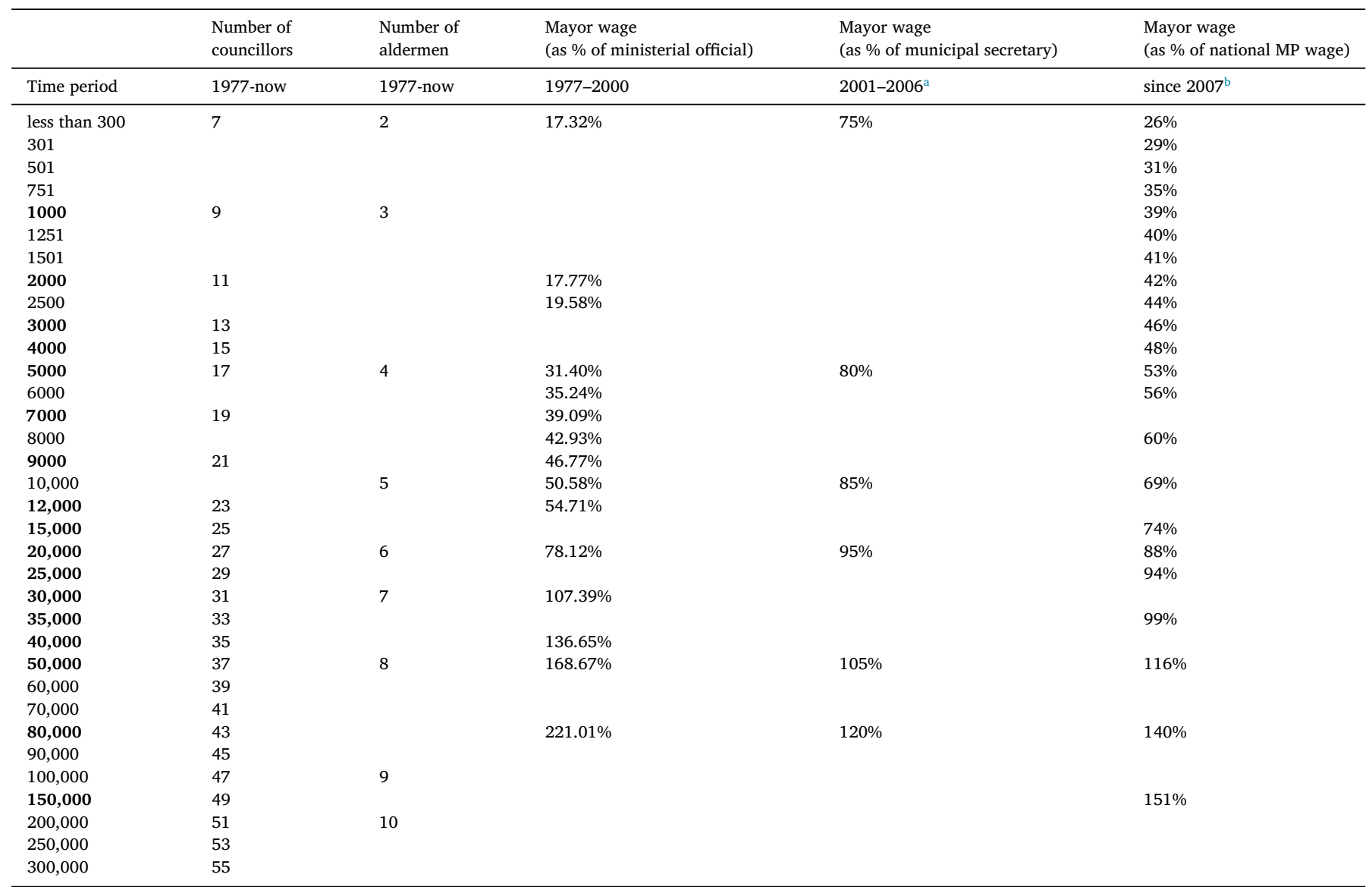

Note: This table represents the number of council members, aldermen and the mayoral wage at different population levels. Boldface population thresholds witness a simultaneous increase in the wage of mayors and aldermen as well as the number of council members at least during part of our time period (1977-2016), and are the focal point of the analysis in the main text. Note also that in the period 1977-2000, the mayoral wage increased in relatively small steps at no less than 152 thresholds between 2000 and 50,000 inhabitants. To preserve space, we only included the main relevant increases in the table.

${ }^{a}$ Implemented by the Law of 4 May 1999.

b Implemented by the Decree of 15 July 2005.

(i.e. 307 observations, or $84 \%$ ) implies moving over the threshold. Moreover, municipalities falling below a threshold generally recover their position above the threshold at some point before the end of our observation period (i.e. 49 observations, or 83\%) - often within the same legislature (21 observations). As shown in Fig. 1, the number of municipalities jumping over a population threshold varies across the legislative periods in our analysis, but is fairly constant across the six years of the electoral cycle. In contrast, municipalities falling below a threshold are largely concentrated in the period prior to 1994 (i.e. 42 out of 59 observations), and is least likely to occur around the election year.

Population figures determining the size of the council and mayor/aldermen remuneration are taken from the national registry (' $R i$ jksregister'). They are initially collected by each municipality's registry office-which records births, deaths and moves at the local level. This information is then centralized in the Rijksregister, which is governed by the Belgian Ministry for Internal Affairs. The latter verifies the information provided by the municipalities, and also cross-references it with the large-scale population surveys held approximately every ten years since 1846 (most recently in 2001). Risk of large-scale outright tampering with the resulting final population figures by Belgian municipalities thus appears unlikely.

\subsection{Data}

For each municipality in Belgium, we collected annual information from the National Institute for Statistics on population size, in- and outmigration, gender and age composition, average real per capita income (in 1000EUR, base year 2000), average net assessed rental value of properties (per capita, base year 2000), ${ }^{7}$ local income and property tax rates, real total public expenditures (per capita, base year 2000), and the absolute number of approved building permits (for apartments, one-family residences, non-residential buildings and renovations). This was complemented with information from the Federal Employment Office on the municipal unemployment rate. Using a wide variety of online sources, we also collected the names and tenures of each municipality's mayors since the municipal amalgamation operation of 1976-77. Information was obtained for 2209 unique mayors covering almost $97.5 \%$ of all municipality-year observations. Summary statistics for all these variables are presented in Table A.1 in Appendix A, which also indicates the

\footnotetext{
7 This net assessed rental value is the tax base for the regional and local property tax (Mahieu et al., 2017).
} 
Crossing population thresholds (by legislative term)

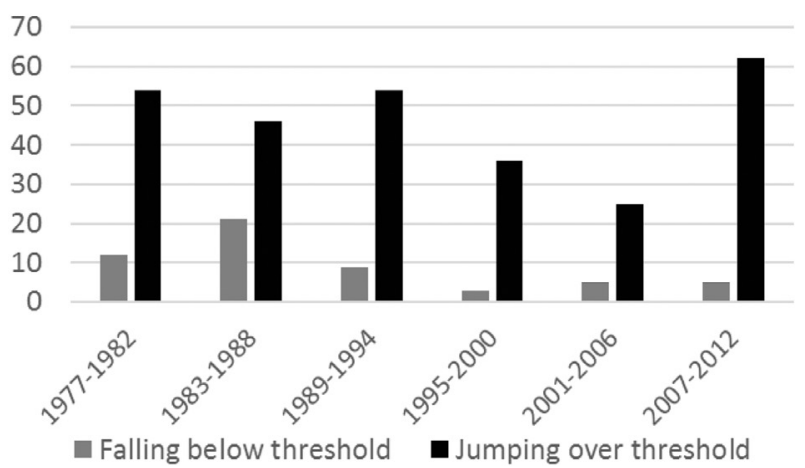

Crossing population thresholds (by election year)

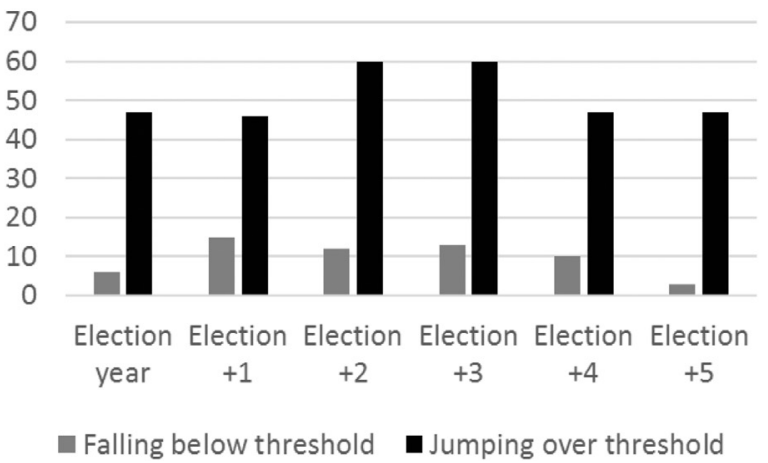

Fig. 1. Number and timing of population threshold crossings.

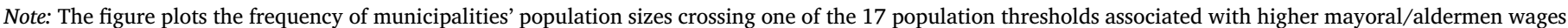

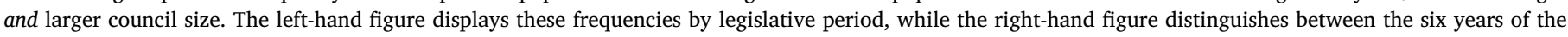
electoral cycle. Black bars represent jumps over a population threshold, whereas grey bars reflect drops below a threshold.

Table 2

Balance test between municipality-year observations just below and above population thresholds.

\begin{tabular}{|c|c|c|c|}
\hline \multirow[t]{2}{*}{ Variable } & Above threshold & Below threshold & \multirow[t]{2}{*}{$p$-value } \\
\hline & \multicolumn{2}{|c|}{ All municipality-year observations near threshold } & \\
\hline Population size & $14,881.06$ & $15,464.66$ & 0.335 \\
\hline Female $(\%)$ & 50.716 & 50.815 & 0.090 \\
\hline Elderly (\%) & 15.203 & 15.683 & 0.002 \\
\hline Income (EUR) & 9.728 & 9.732 & 0.969 \\
\hline Unemployment (\%) & 3.819 & 3.640 & 0.048 \\
\hline Kadastral income (EUR) & 472.998 & 479.268 & 0.580 \\
\hline Expend/cap (EUR) & 780.133 & 787.077 & 0.604 \\
\hline \multirow[t]{2}{*}{ Flanders $(=1)$} & 0.502 & 0.524 & 0.324 \\
\hline & \multicolumn{2}{|c|}{ Only municipality-year observations from municipalities crossing threshold } & \\
\hline Population size & $15,969.86$ & $15,162.65$ & 0.366 \\
\hline Female $(\%)$ & 50.601 & 50.859 & 0.002 \\
\hline Elderly (\%) & 14.731 & 15.410 & 0.002 \\
\hline Income (EUR) & 9.862 & 9.623 & 0.121 \\
\hline Unemployment (\%) & 3.718 & 3.632 & 0.437 \\
\hline Kadastral income (EUR) & 490.259 & 486.970 & 0.818 \\
\hline Expend/cap (EUR) & 772.305 & 773.744 & 0.934 \\
\hline Flanders $(=1)$ & 0.501 & 0.511 & 0.740 \\
\hline
\end{tabular}

Note: The table includes only the sample of municipalities whose population size is within $2 \%$ of a population threshold associated with higher mayoral wages and council size. On the left-hand side are municipalities just above the population threshold, while on the right-hand side are municipalities just below the threshold. $p$-value refers to the statistical significance of a two-sided $t$-test assessing the difference between both subsamples.

time-period availability for all variables. As can be seen in Table A.1, the average tenure of Belgian mayors just exceeds ten years, which equals almost two legislative terms (a more complete distribution of mayor tenures is provided in Fig. X.1 in the online appendix).

Table 2 evaluates whether municipalities just below and above our main population thresholds are similar in terms of several sociodemographic characteristics (using a $2 \%$ window around the thresholds). The results from difference-in-means $t$-tests included in the last column of Table 2 indicate some statistically significant differences between both groups, although these remain substantively very small. As similar results are obtained when replicating the analysis for other window sizes around the thresholds, we include socio-demographic controls throughout our analysis to avoid biased inferences (see below) and return to the choice of our evaluation window below.

\section{Empirical strategy}

Our estimation approach is based on the following regression model (with subscripts $i$ and $t$ for municipalities and time, respectively):

$Y_{i t}=\alpha_{i}+\beta_{1}$ Population Threshold ${ }_{i t}+\delta X_{i t}+\gamma_{t}+$ Trend $_{i}+\varepsilon_{i t}$

In Eq. (1), $Y_{i t}$ represents a set of dependent variables reflecting housing or fiscal policy parameters in municipality $i$ at time $t$. Housing policy is captured by the absolute number of building permits for, respectively, residential properties (either apartments or one-family residences), nonresidential properties, or renovations of residential buildings. We consider the absolute number as this reflects the number of subsequent constructions, which is what matters for reaching the next population threshold. Fiscal policy is operationalised using the tax rates for the two main fiscal instruments available to Belgian local governments: i.e. surcharges on the federal personal income tax and the regional property $\operatorname{tax}^{8}$

\footnotetext{
8 These two taxes, on average, represent more than $80 \%$ of municipal fiscal revenues. Since fiscal revenues cover approximately $40 \%$ of total municipal revenues, both taxes on average account for just over one third of local revenues. People are very aware of both taxes and their fiscal burdens as major newspapers devote articles to the differences in municipal taxes on a yearly basis. Moreover, although the weight of local income taxes in
} 
The key independent variable - Population Threshold $_{i t}$ - is an indicator variable equal to 1 for municipality $i$ whose population size in year $t$ is within a given bandwidth around a population threshold associated with higher remuneration of mayors and aldermen and larger council size ( 0 otherwise). As always, the window size or bandwidth must balance the requirement for a sufficient number of observations 'treated' with a particular policy and adding variation not directly attributable to this policy when expanding the window size. To assess the robustness of our findings, we work with window sizes between $0.1 \%$ and $5.9 \%$ (with $0.1 \%$ increments). We thereby account for the exact time period any particular threshold has been legally valid, and take the year of the official publication of legal changes as indicative of the latest possible moment municipal leaders become aware of changes in the applicable thresholds. While no changes have been implemented to the thresholds affecting the number of councillors and aldermen since the municipal amalgamations in 1976-77, the thresholds determining mayoral wages were changed by the law of 4 May 1999 and the decree of 15 July 2005 (see Table 1). Hence, our operationalisation of Population Threshold ${ }_{i t}$ allows for the fact that local officials could already respond to the new thresholds from, respectively, 1999 and 2005 onwards. We differentiate between municipalities just below and just above relevant population thresholds, and expect $\beta_{1}<0$ particularly among the former group. ${ }^{9}$

$X_{i t}$ is a vector of control variables, which differs slightly across the housing and fiscal policy models. Population size is a critical control in both models because it represents the running variable underlying the treatment assignment. In the housing policy model, we also include income per capita, unemployment rate, share of elderly (age over 65) and share of women to account for observed minor imbalances in these characteristics between municipalities close to and further from a population threshold (see Table 2). We additionally include net in-migration (as a share of population) to capture that demand for new housing directly affects the number of permits. In the fiscal policy model, we add several controls reflecting first-order drivers of tax policy including the size of the respective tax bases (i.e. income per capita for the income tax and net assessed rental value of property for the property tax), total local government spending (to capture local governments' funding requirements) and the share of unemployed and elderly (which affect jurisdictions' ability to raise revenues through different tax sources) (see, e.g., Hettich and Winer, 1988; Geys and Revelli, 2011).

We furthermore add fixed effects at municipality level $\left(\alpha_{i}\right)$ and year $\left(\gamma_{t}\right)$. The municipality fixed effects control for location-specific heterogeneity, and effectively imply that we draw inferences from variation in municipality-specific developments before/after reaching a relevant population threshold. The year fixed effects capture variation that is constant across all municipalities in a given year. Throughout all models, we also include (linear) municipality-specific time trends $\left(\right.$ Trend $_{i}$ ), which explicitly allow municipalities' characteristics to be on distinct temporal trends. This is arguably of particular relevance when there is a gradual treatment (as in our setting). Finally, we cluster standard errors at the municipality level throughout all estimations.

Methodologically, it is important to note that we pool observations across all population thresholds over time in our analysis. This is necessary because there are too few observations in the immediate vicinity of each individual threshold (see also footnote 13). Moreover, we focus on

total income taxes is relatively small (i.e. less than $10 \%$ on average), property taxes are predominantly a local-level tax (i.e. more than $90 \%$ of revenues at the local level). There are no local sales taxes in Belgium, and local business taxes (which cover less than $8 \%$ of local tax revenues on average) have only limited comparability across municipalities, which impedes their inclusion in our analysis.

${ }_{9}$ Auxiliary regressions confirm that an increase in residential building permits induces faster population growth and net in-migration in subsequent years. This effect is strongest one or two years after the increase in residential building permits, and levels off afterwards. There is no instantaneous effect of increased building permits, and increases in non-residential building permits show no statistically significant effects on population growth and net in-migration. Full details are provided in table X.1 in the online appendix. changes around population thresholds using a difference-in-differences approach (Lee and Lemieux, 2010). The reason is that while municipal population parameters and policies are likely to differ in the vicinity of specific thresholds, sharp discontinuities at the thresholds are improbable. Therefore, our paper differs from applications that focus on changes at the thresholds using a standard Regression Discontinuity design (which identify a shift in levels; Hahn et al., 2001), or Regression Kink design (which identify a shift in slopes; Card et al., 2015). Moreover, municipalities have an incentive to adjust housing and fiscal policy at some point before reaching the threshold since their effects on population growth will not be instantaneous (see also footnote 9). Given that the 'optimal' moment for such policy shifts is hard to determine a priori - as it depends on one's position in the electoral cycle and population responsiveness-standard Regression Discontinuity or Regression Kink designs are unfeasible to address our research question (see also identification and inference issues outlined by Card et al., 2015).

Finally, municipalities growing or shrinking towards important population thresholds have similar incentives to position themselves on the right side of the threshold. Nonetheless, this requires policy changes at different positions for both sets of municipalities: i.e. growing municipalities should change policies while below the threshold, while shrinking municipalities should do so while still above the threshold. Hence, from a conceptual point of view, pooling both sets of municipalities is inappropriate. Given the small number of municipalities falling below a threshold over the period of observation and the concentration of such events in the time period lacking information on local housing policy (see Section 2.1 above), the analysis below focuses on municipalities growing towards important population thresholds. In practice, this implies that we exclude 38 municipality-legislatures witnessing a fall below a population threshold (which is less than one percent of all 4123 municipality-legislatures in the complete sample).

\section{Findings}

\subsection{Bunching around the threshold}

As a first step in our analysis, we test for bunching behaviour around our 17 main thresholds. We follow Eggers et al. (2018) in calculating the difference between municipalities' population sizes and the closest relevant population threshold for all municipalities in all years. We then store all municipality-years when a municipality's population size lies within $\mathrm{x} \%$ of a threshold (with $x=1, \ldots, 5$ ), and also experimented with absolute cut-offs at 100, 250 and 400 inhabitants around a threshold. None of these alternatives affected our inferences. Fig. 2 plots the results using a cut-off at 250 inhabitants and a bin width of 5 .

Fig. 2 does not appear to substantiate significant bunching in the immediate vicinity of important population thresholds in Belgian municipalities. As a formal assessment, we calculated the McCrary (2008) test statistic, which confirms the absence of a discrete shift in the density at the threshold. Although the McCrary test statistic is positive, it remains relatively small and is not statistically significantly different from zero $(0.196 ; p>0.10)$. Similar insignificant results arise when splitting the sample in small and large municipalities, independent of where we set the cut-off between both groups. Nevertheless, estimating a thirddegree fractional polynomial on the frequency distribution underlying Fig. 2 suggests a local maximum in the density at approximately +80 (see solid line in Fig. 2). ${ }^{10}$ Although municipalities thus may not be able to situate themselves just right of the threshold, they can-and ostensibly do-influence their general position on the right side of the threshold. Hence, the absence of bunching at the threshold in Fig. 2 is

\footnotetext{
10 Interestingly, studying Spanish local governments Foremny et al. (2017) show that municipalities close to population thresholds inducing higher per capita grant allocations on average over-report their population by 62 inhabitants.
} 


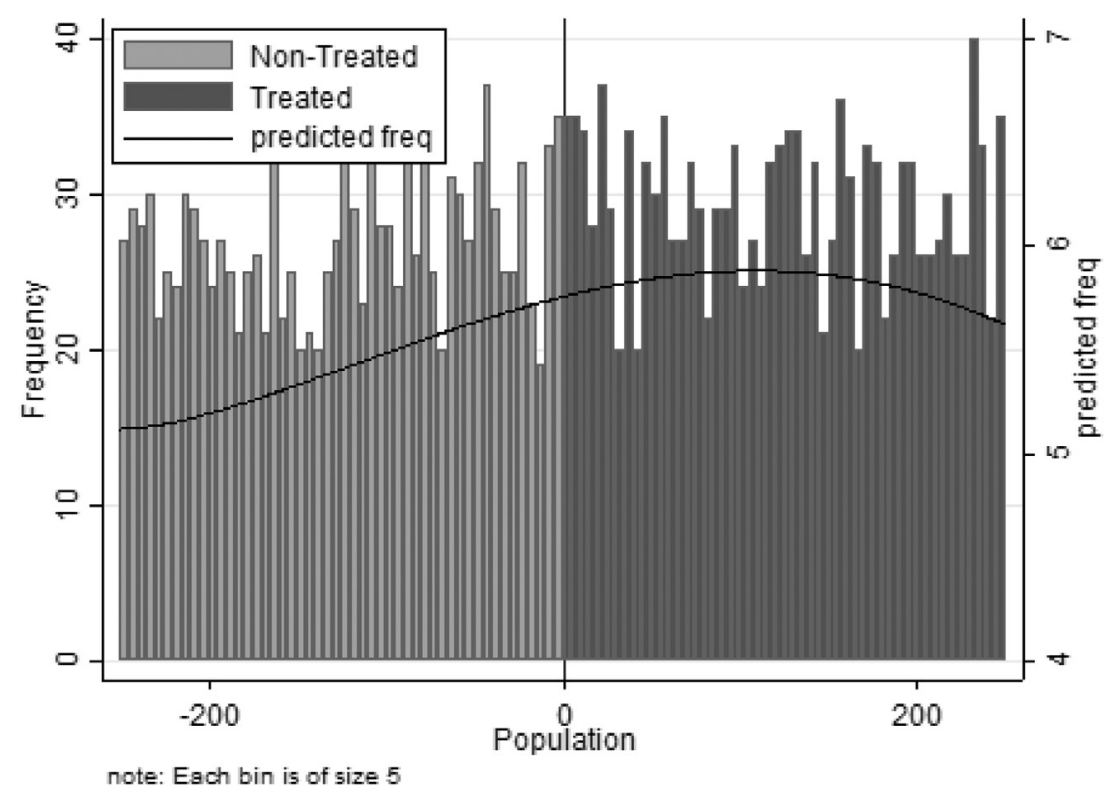

Fig. 2. Clustering around population thresholds.

Note: The figure plots the distribution of municipalities' population sizes within a 250-person window around the 17 population thresholds associated with higher mayoral/aldermen wages and larger council size. Each bin in the histogram is of size 5 (left-hand scale). The vertical axis designates the population threshold(s), with negative (positive) numbers indicating the number of inhabitants below (above) a threshold. The line represents a fractional-polynomial prediction plot of the frequency distribution of municipalities around the population thresholds with a polynomial function of third degree (using a bin size of 1 in the underlying estimation, right-hand scale).

not a necessary, nor a sufficient, condition to reject strategic local-level policies aimed at stimulating desired population developments.

To explain this result, we should bear in mind that-unlike outright manipulation of population figures (Litschig, 2012; Foremny et al., 2017) - policy measures aimed at stimulating population growth cannot be expected to fine-tune municipalities' position immediately above the threshold. Moreover, there is uncertainty regarding "the regular connections between [policy] instruments and outcomes" (Chappell and Keech, 1986: 71; see also Tufte, 1980; Wieland, 2000), as well as coordination problems when policy actions are implemented at various levels of government or within different departments at the same level of government (see Franzese, 2002, for similar arguments concerning the difficulty of timing desirable socio-economic outcomes around elections). As a result, local office-holders may well be 'playing safe' to avoid the risk of just missing the threshold.

\subsection{Housing policies as mechanism}

A first plausible means to attract future inhabitants lies in local housing policy since municipalities generally have considerable autonomy over spatial planning decisions (Solé-Ollé and Viladecans-Marsal, 2012; Chanel et al., 2014). In our setting, such autonomy over spatial planning may imply that municipalities close to, but below, an important population threshold become less restrictive in granting building permits, or stimulate the construction of residential housing via the allotment of new settlement areas. ${ }^{11}$ From this perspective, it is important to observe

\footnotetext{
11 Gerrymandering and municipal amalgamations are other means to increase population size. In the Belgian setting, however, there is no possibility of gerrymandering. Moreover, mergers were no longer an issue following the large-scale amalgamation operation in 1976-77. Although this changed in 2016 when the Flemish regional government started offering financial incentives for mergers, no mergers have as yet been implemented. Even so, a merger decreases local office-holders' probability of retaining power, which mitigates their personal incentives for municipal amalgamations (besides the larger prestige for office-holders).
}

that the process of awarding building permits in Belgian municipalities provides substantial room for interpretation by local policy-makers. As such, there is no need for them to change the underlying regulations or permit process when approaching a relevant population threshold, which would take more time and be politically more sensitive than a temporary 'flexible' interpretation of existing rules and procedures.

Exploring this mechanism, we estimate Eq. (1) using window sizes between $0.1 \%$ and $5.9 \%$ (with $0.1 \%$ increments). Yet, we lag our main explanatory variable with one year as it usually takes at least one year to validate the building permit and construct and occupy the new accommodation. We summarize the main findings in Fig. 3, which analyses building permits for apartment buildings (top left), one-family residences (top right), renovations of residential buildings (bottom left) and non-residential buildings (bottom right). Fig. 3 always separates municipalities close to but below the threshold (left-hand side) from municipalities close to but above the threshold (right-hand side). Details of the estimation results are provided in Table X.2 in the online appendix.

Fig. 3 illustrates that the effect of being just above important population thresholds on the number of approved building permits is never statistically significant - independent of the type of permit under consideration. When looking instead at municipalities just below important population thresholds, we find a substantial effect on building permits for apartments that is (close to) statistically significant at the $90 \%$ confidence level at widow sizes ranging from $0.8 \%$ to $2.9 \%$. This difference below and above the population thresholds is important since local governments have direct control over housing policy decisions, and can thus target the approval of building permits to their perceived need in terms of surpassing a population threshold. The size of the coefficient estimates suggests that, on average, six to nine additional building permits for apartments are approved when a municipality's population size is nearing an important threshold. This is equivalent to $15-23 \%$ of the average annual number of building permits for apartments (or $7-11 \%$ of its standard deviation). There is also a smaller effect on permits for renovations of residential buildings (approximately 1.5 additional permits on 

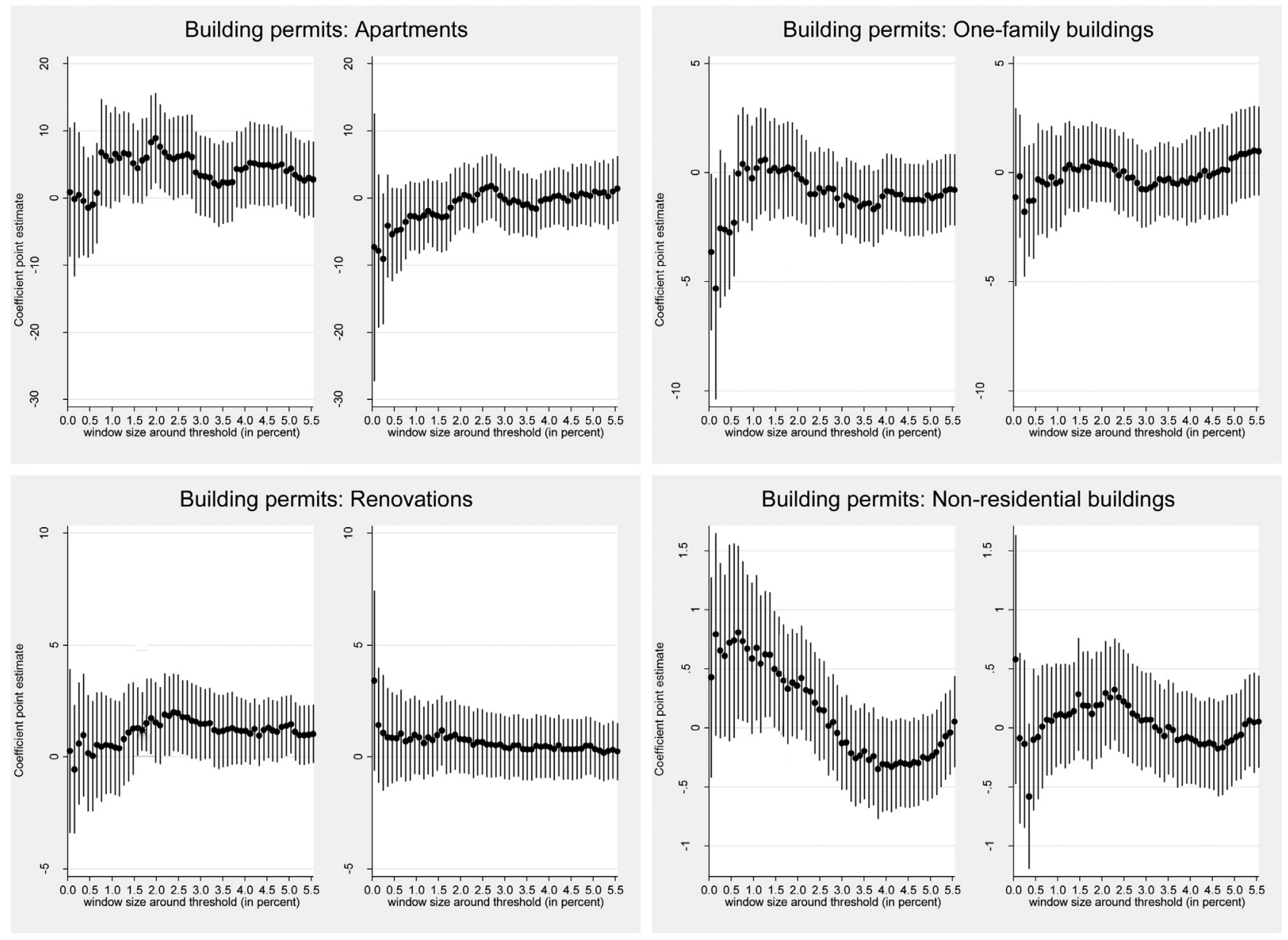

Fig. 3. Housing policy near population thresholds.

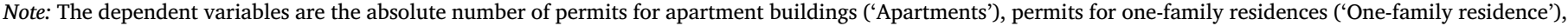

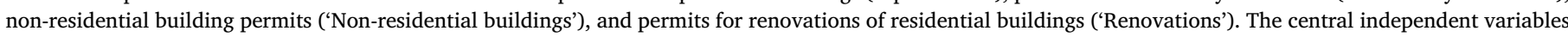

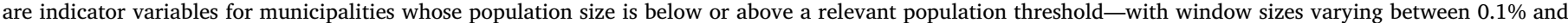

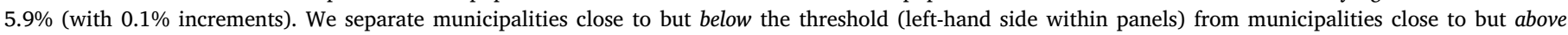

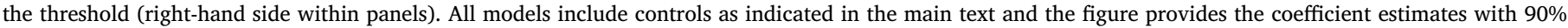
confidence intervals (using standard errors clustered at the municipality level).

average), but no significant effect on building permits for one-family residences. ${ }^{12}$ This apparent focus on building permits for apartments makes intuitive sense if the goal is to reach and surpass the population threshold as quickly as possible. One-family residences are less 'efficient' compared to new apartments since they consume more open space (which is becoming a scarce commodity in many Belgian municipalities) and take longer to construct for a given 'return' in terms of additional residents. Overall, Fig. 3 thus suggests that local governments nearing a population threshold target their housing policy towards options promising the largest possible population growth in the short term.

\subsection{Fiscal policies as mechanism}

Another plausible instrument to attract inhabitants is local fiscal policies. Taxation and public expenditure decisions are deemed of central relevance to individuals' and firms' location decisions in the

\footnotetext{
12 The results on permits for non-residential buildings are exceedingly sensitive to the window size in terms of both sign and statistical significance. Hence, we cannot confidently draw inferences from these findings. Note also that all inferences drawn here are qualitatively unaffected when log-transforming our dependent variables, although in this case we observe a significant drop in building permits for apartments after a relevant population threshold is surpassed (see Table X.6 in the online appendix for details)
}

tax and yardstick competition literatures (Wilson, 1986; Zodrow and Mieszkowski, 1986; Bordignon et al., 2003; Geys and Osterloh, 2013). Indeed, even when an individual or firm judges a certain municipality to be an optimal location for whatever reason (e.g., closeness to relatives, clean air, and so on), "there might still be some degrees of freedom in choosing the specific community" (Buettner, 2001: 226). This leaves leeway for municipalities to employ fiscal policies to attract the mobile tax base. Belgian municipalities have relatively high autonomy over their tax policy (Vermeir and Heyndels, 2006; Geys and Revelli, 2011), and can freely set the tax rates for their two main fiscal revenue sources: the local income tax (a surcharge on the federal income tax) and the local property tax (a surcharge on regional property tax). Moreover, these tax rates receive significant attention in newspapers, such that citizens are aware of them and their financial implications (see also footnote 8).

Exploring this potential mechanism, Fig. 4 presents results from estimating Eq. (1) using these two tax rates as the respective dependent variables. We again separate municipalities close to but below the threshold (left-hand side within each panel) from municipalities close to but above the threshold (right-hand side within each panel), and we lag our main explanatory variable with one year since tax rate decisions are taken the year prior to their implementation. Details of the estimation results are provided in Table X.2 in the 

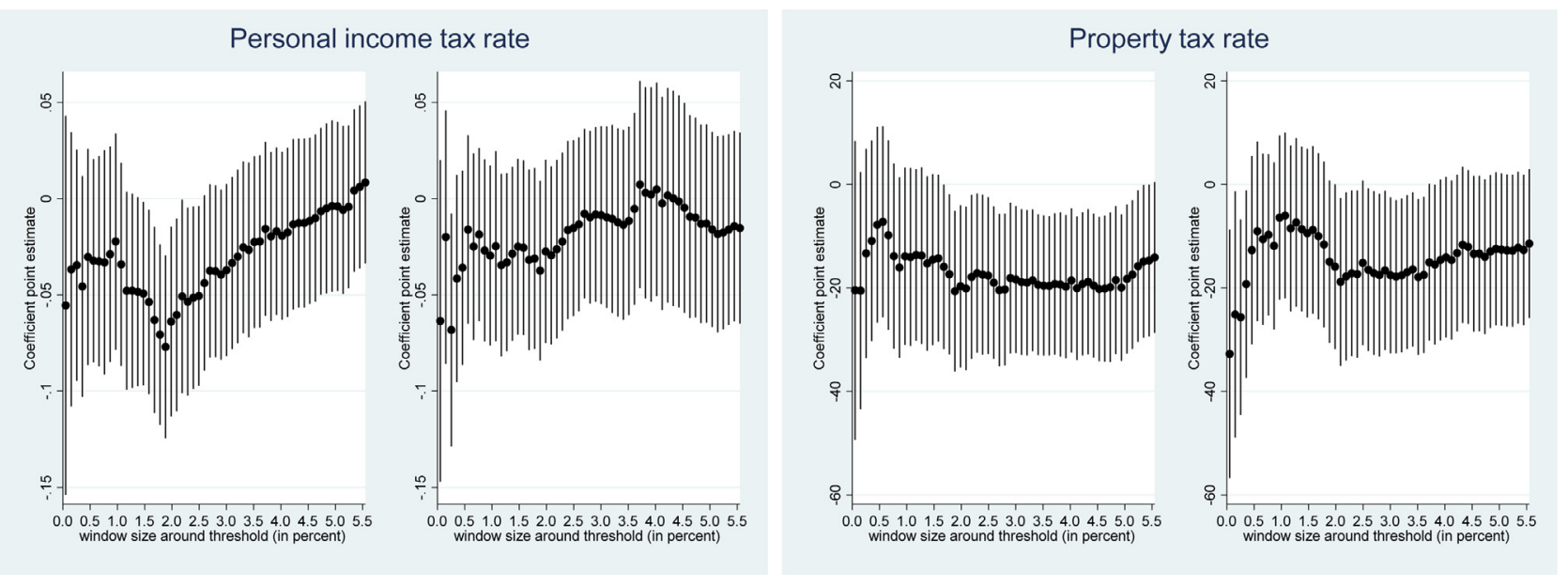

Fig. 4. Fiscal policy near population thresholds.

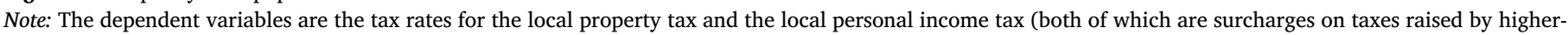

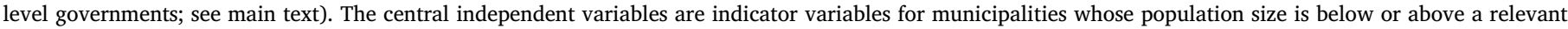

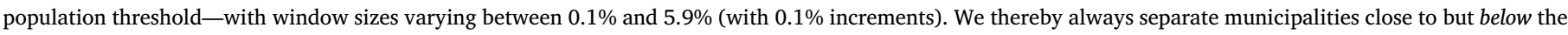

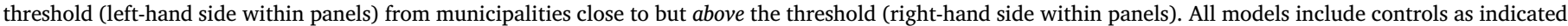
in the main text and the figure provides the coefficient estimates with $90 \%$ confidence intervals (using standard errors clustered at the municipality level).

online appendix (and Table X.6 using a log-transformed version of the dependent variable).

The coefficient estimates in Fig. 4 are almost consistently negative. Given that tax rates show a tendency to increase over time across Belgian municipalities (with $0.04 \%$ on average per year for the personal income tax and 22.5 points per year for the property tax), this suggests that municipalities close to an important threshold increase their tax rates less strongly. We observe statistically significant point estimates when municipalities are approaching a threshold from below using window sizes ranging from $1.2 \%$ to $2.6 \%$ for the personal income tax rate and window sizes ranging from $1.7 \%$ to $5.8 \%$ for the property tax rate. The estimated effect size in these ranges equals $0.05-0.09 \%$ for the income tax and 18-20 points for the property tax. Both are substantively meaningful given the average size of yearly tax rate increases (see above), and thus indicate that municipalities nearing a threshold are keen to improve their fiscal attractiveness to potential residents. Interestingly, the point estimates above the threshold are still negative and often (close to) statistically significant especially for the property tax. This most likely reflects that municipalities crossing the threshold do not immediately readjust their tax rates (we return to this timing issue in the next section). Overall, therefore, Fig. 4 provides evidence in line with the idea that local governments nearing a population threshold make fiscal decisions aimed at attracting more inhabitants. ${ }^{13}$

Although the potential welfare loss of the housing policy changes observed above is extremely hard to quantify, we can provide a backof-the-envelope calculation for the revenue cost of the observed tax reductions (or foregone increases) per Euro of extra pay for the mayor and

\footnotetext{
13 An anonymous referee pointed out that the different thresholds in our analysis may have distinct effects due to variation in the exact relation between changes in population size and changes in reelection odds of local office-holders at specific thresholds. Unfortunately, the limited number of observations around each threshold in our sample requires at least some pooling across thresholds and years to obtain sufficient observations and statistical power. As an admittedly imperfect approximation, we replicated our main analysis for samples above and below 10000 inhabitants (which splits the sample roughly in half and is not an otherwise relevant threshold within our analysis). We find that our effects on housing permits for apartments as well as the property tax rates are driven by larger municipalities, while smaller municipalities drive our findings for the personal income tax rates (see Table X.5 in the online appendix). While the reason for these opposing effects across both tax rates might be linked to the stronger reliance on property (income) taxation among smaller (larger) municipalities, this finding would require further verification in future research.
}

aldermen that arises from crossing a threshold. Due to data restrictions on tax-specific revenues, we take the example of municipalities within a $2 \%$ window under the remuneration-relevant 20,000-inhabitant threshold in 2013. ${ }^{14}$ By passing the threshold, the mayor would increase her remuneration from $88 \%$ to $94 \%$ of the wage of a member of parliament (i.e. 81,106 EUR) (see Table 1), which amounts to a yearly difference of 4,867 EUR. As aldermen earn $60 \%$ of the mayoral income and increase in number from 5 to 6 by crossing the threshold, the total wage bill for aldermen increases by 60,344 EUR. The increased wage cost for mayor and aldermen thus equals 65,211 EUR. This can be compared to the total forgone tax revenue due to a foregone increase of 18 points in the property tax rate and $0.05 \%$ of the income tax rate (see Fig. 4). In 2013 - the latest data available - the six municipalities under consideration collected on average 622,727 EUR per percent of income tax rate and 4,697 EUR per point of property tax rate. Hence, the estimated income tax revenue loss would be 31,136 EUR and the estimated property tax revenue loss 84,546 EUR. Total forgone tax revenue amounts to 115,682 EUR, which equals 1.77 EUR per Euro of extra pay for the mayor and aldermen.

\subsection{Elections and policy timing}

Given that the population thresholds expressly apply to the municipality's number of inhabitants on January 1 of the election year since 2001 (see Section 2.1), local governments have gained an incentive to focus on this date to surpass the threshold. The reason is that surpassing the threshold during or after an election year is less immediately 'rewarding' in terms of higher mayor/aldermen remuneration and a larger council size compared to crossing it just before an election year. This implies that from 2001 onwards policy decisions to boost the number of inhabitants should be taken some years before the next election, such as to-hopefully-induce higher population growth in years immediately preceding the election year. In this section, we assess the empirical prevalence of election-driven temporal patterns in policy developments by extending Eq. (1) with a set of interaction terms between Population Threshold ${ }_{i t}$ and indicator variables for different years in the election

\footnotetext{
14 This corresponds to six municipalities: Aalter, Blankenberge, Dilsen, Poperinge, Tielt and Wuustwezel. To assess the external validity of the example, recall that the average Belgian municipality has roughly 19000 inhabitants.
} 
cycle (Election). We specifically introduce interaction terms for one, two, three and four years prior to the election $(e=-1,-2,-3,-4)$. The remaining two years $(e=0,-5)$ of the six-year election cycle act as the reference category:

$$
\begin{aligned}
Y_{i t}= & \alpha_{i}+\beta_{1} \text { Population Threshold }_{i t} \\
& +\theta \text { Election }_{e} \text {.Population Threshold } \\
i t & +\delta X_{i t}+\gamma_{t}+\text { Trend }_{i}+\varepsilon_{i t}
\end{aligned}
$$

To retain sufficient municipalities close to a population threshold in the different years of the election cycle, we set Population Threshold Tit $_{\text {equal to }} 1$ for municipalities within a $2 \%$ window above and below a relevant threshold. ${ }^{15}$ Identification here derives from the fact that different municipalities approach a population threshold during different election years. Hence, even though all municipalities hold elections on the same day (such that election years are perfectly collinear with the year effects $\gamma_{t}$ ), we can nonetheless differentiate between year and election effects in the analysis. For ease of interpretation, the results are graphically presented in Fig. 5 for the three variables showing the strongest results in the previous two sections: i.e. apartment building permits (top panel), the personal income tax rate (middle panel) and the property tax rate (bottom panel). In each panel, observations before and after 2001 are used on the left- and right-hand side, respectively (the top right panel is missing as housing permit data are only available since 1996). As confidence intervals tend to be wide due to the limited number of observations across the election cycle, we suppress confidence intervals for readability and indicate statistical significance using asterisks on the horizontal axis labels.

Fig. 5 highlights that in the period after January 1, 2001 the number of additional approved building permits for apartments and the reduction in the two main local tax rates tend to be largest in municipalities nearing a population threshold when the election-and thus the 'deadline' to surpass the population threshold-is still some way into the future. These effects are statistically significant at the $90 \%$ confidence level for both tax rates (in $e-3$ and/or $e-4$ ), and the $95 \%$ level for housing permits (in $e-3$ ). The effects converge towards 0 when the election is imminent, and are never statistically significant in the period before January 1, 2001 (when election years were not used as cut-off for crossing the population thresholds). All in all, despite limited statistical power in these tests, our findings are in line with the idea that local governments take into account the time it takes for building permits and fiscal policy changes to translate into increased population size (see also footnote 9).

\subsection{Does crossing a population threshold benefit the incumbent?}

The incentive to cross a population threshold is arguably larger when local politicians are more confident that they can benefit from this themselves. The personal economic incentive decreases when one fears electoral defeat at the next elections. We assess this proposition in two ways. First, we analyse whether the incumbent mayor benefits from passing a population threshold by looking at her probability of remaining in power in a subsequent legislative period. The results are provided in Table 3 for the 3891 available mayor-legislature observations in the 1977-2012 period (we exclude the current 2013-2018 legislative period as it is impossible to know whether current mayors will return in the future). This indicates that a mayor, on average, has a roughly $60 \%$ chance of being reappointed in a future legislative term. There is no evidence that passing a population threshold substantively nor significantly improves the probability to be reappointed (Fischer's exact $p=0.753$ ). ${ }^{16}$

\footnotetext{
15 Unfortunately, focusing only on municipalities approaching the population threshold(s) from below is impossible due to the lack of sufficient observations in each year of the election cycle. Note also that the results reported here are robust to an extended window size of $3 \%$.

${ }^{16}$ This is also confirmed when using a logit model where the dependent variable is 1 when the mayor is reappointed in a future legislative term ( 0 otherwise) and the key
}

Table 3

Mayor reappointment.

\begin{tabular}{llll}
\hline & \multirow{2}{*}{ All observations } & \multicolumn{2}{l}{ Crossed population threshold } \\
\cline { 3 - 4 } & & NO & YES \\
\hline Mayor not reappointed & $40.61 \%$ & $40.64 \%$ & $39.58 \%$ \\
Mayor reappointed & $59.39 \%$ & $59.36 \%$ & $60.42 \%$ \\
$\mathrm{~N}$ & $N=3891$ & $N=3568$ & $N=283$ \\
Pearson $\mathrm{Chi}^{2}(1)$ & & 0.123 & \\
Fisher's exact & & $p=0.753$ & \\
\hline
\end{tabular}

Note: This table presents the share of mayors in power at time $t$ who are reappointed as mayor during a future legislative period. Column 1 includes all available municipality-legislature observations, whereas columns 2 and 3 distinguish between legislatures depending on whether or not the municipality's population crosses a population threshold. The Pearson $\mathrm{Chi}^{2}$ test statistics evaluates the statistical significance of the difference in both distributions, with a p-value obtained using Fisher's exact method.

This appears intuitively reasonable, and implies that mayors have no reelection-based motive to pass a relevant population threshold, merely a financial one.

Second, although the need for coalition governments-which occur in roughly $60 \%$ of all local government formations in Belgium (Geys, 2007) -increase uncertainty about future spells in power, pre-electoral agreements setting out the terms and partners of a coalition government after upcoming elections are very common at the local level in Belgium (Wille and Deschouwer, 2012). Such agreements naturally increase the predictability of succeeding/failing to return to power (subject to obtaining a majority position in the local council). Therefore, local officeholders often have realistic expectations about their (potential to) return to power. To test whether these expectations affect our results, Table 4 differentiates between municipality-legislature observations where the mayor does return to power in a future legislative period (first three columns), and those where the mayor does not return to power (either because she voluntarily steps down or is ousted from power; last three columns). The results suggest that apartment permit increases are only implemented by mayors who (expect to) return to power, but do not arise for mayors (expecting to be) no longer in power. Hence, we can confirm the existence of strategic housing policy decisions only if it benefits the incumbent leadership. Interestingly, however, a similar pattern is not observed for fiscal policy decisions.

\subsection{Placebo tests}

Finally, we report the results of two placebo tests. The first of these consists of repeating the analysis at population thresholds where no policy changes occur. In particular, we choose the midpoint between the currently valid population thresholds and the next threshold included in Table 1 , and then add 167 to the result to make sure we do not accidentally include a real population threshold (for a similar approach, see Eggers et al., 2018). As such, we set 12 placebo thresholds at 1392, 2417, 3667, 4667, 5667, $17,667,22,667,27,667,37,667,55,167,85,167$ and 175,167. The results are presented in Table X.3 of the online appendix for five window sizes ranging from $0.9 \%$ to $4.9 \%$. Coefficient estimates are small and remain statistically insignificant at conventional levels, except those for the property tax rates (where we find significant negative point estimates for small window sizes). The second placebo test changes the lag

explanatory variable is 1 when the municipal population crosses a population threshold in a given legislative term ( 0 otherwise). Full details in Table X.7 in the online appendix. 


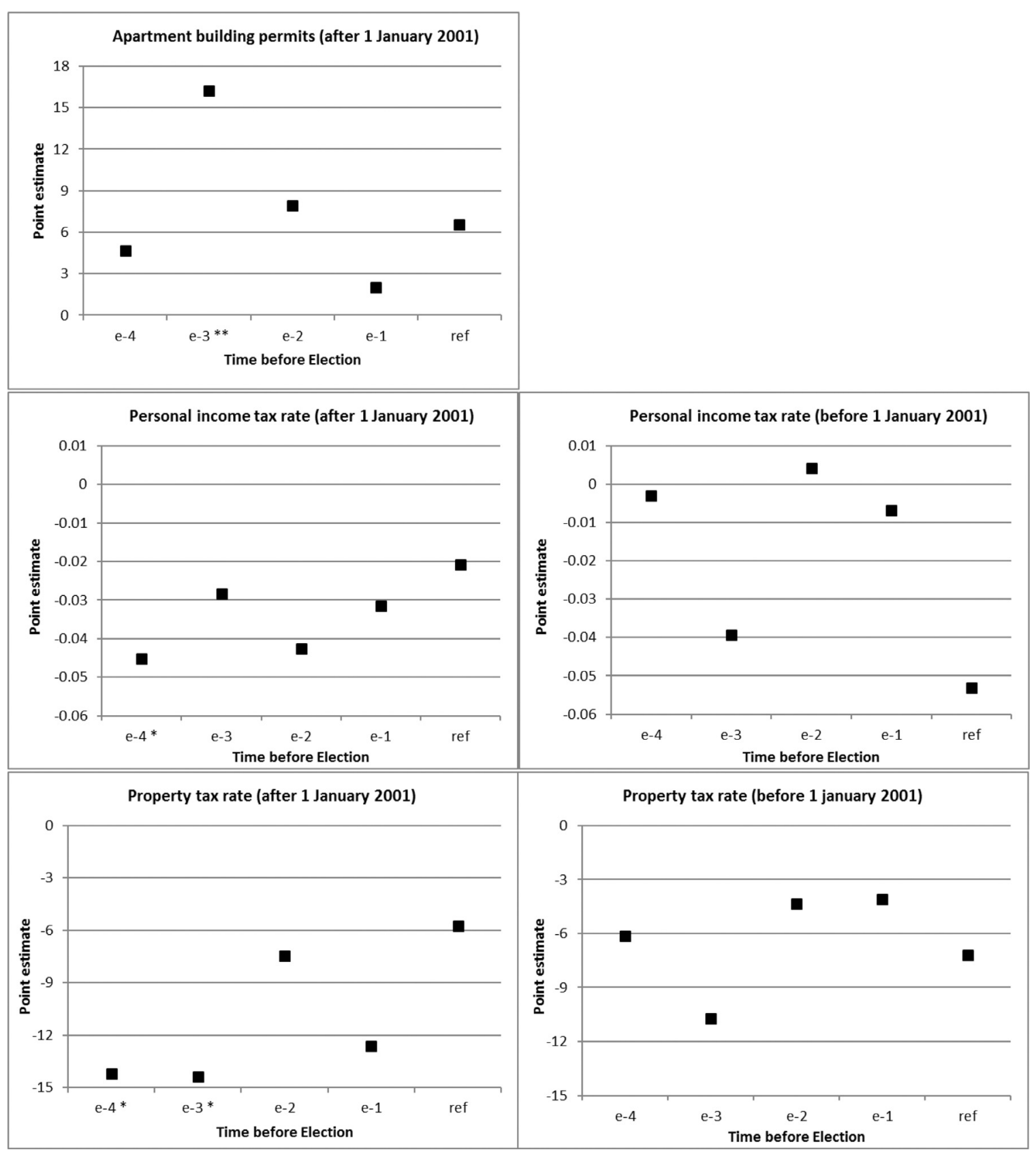

Fig. 5. Housing and fiscal policy near population thresholds throughout the election cycle.

Note: The dependent variables are the absolute number of permits for apartment buildings (top panel), the local personal income tax rate (middle panel) and the local property tax rate (bottom panel). The figure shows point estimates for the independent variables, which are indicator variables for municipalities whose population size is $2 \%$ below or above a relevant population threshold interacted with indicator variables reflecting the time until the next election (1, 2, 3, or 4 years). We separate the period before January 1, 2001 (right-hand side) and after January 2001 (left-hand side) as elections only became the relevant population cut-off from this point onwards. The top right panel is missing as housing permit data are only available since 1996, and do not permit credible estimation of election-cycle effects prior to 2001. All models include controls as indicated in the main text. We suppress confidence intervals for readability and indicate statistical significance using asterisks on the horizontal axis labels: ${ }^{* * *}$ significant at $1 \%,{ }^{* *}$ at $5 \%$ and ${ }^{*}$ at $10 \%$.

structure in our analysis. The idea is that introducing a one-year forward lag of our central explanatory variable should lead to insignificant results, since incentives for strategic policy decisions disappear after a municipality has passed the population threshold. This is borne out by the empirical analysis in Table X.4 in the online appendix, once again with the main exception of the local property tax rates.

Overall, these results confirm that our main results relating to housing permits for apartments and personal income tax rates are credibly linked to approaching the actual population thresholds that increase mayor/aldermen remuneration and the council size. The results for the local property tax rates are perhaps less compelling based on their persistence in these placebo checks. Still, this may at least in part reflect the extreme stability of the local property tax rate over time. The tax rate remains unchanged in over $85 \%$ of our municipality-year observations, and $77.6 \%$ of all municipalities make at most one change per legislature in the property tax rate. From this perspective, the credibility of 
Table 4

Results for mayors succeeding/failing to return to power (at selected window sizes).

\begin{tabular}{|c|c|c|c|c|c|c|}
\hline \multirow[t]{2}{*}{ Variable } & Apartments & Personal income tax rate & Property tax rate & Apartments & Personal income tax rate & Property tax rate \\
\hline & \multicolumn{3}{|c|}{ Mayor returns to power in future period } & \multicolumn{3}{|c|}{ Mayor does not return to power in future period } \\
\hline & \multicolumn{6}{|c|}{ Panel I: window size $1 \%$} \\
\hline \multirow[t]{2}{*}{ Below population threshold (lag) } & $20.015 * * *$ & -0.036 & -10.429 & -11.212 & -0.019 & -6.568 \\
\hline & $(7.300)$ & $(0.039)$ & $(15.218)$ & $(7.078)$ & $(0.040)$ & $(10.492)$ \\
\hline \multirow[t]{3}{*}{ Above population threshold (lag) } & 5.238 & -0.020 & -14.553 & -5.804 & 0.033 & 4.062 \\
\hline & $(5.431)$ & $(0.035)$ & (14.129) & $(6.752)$ & $(0.044)$ & $(10.401)$ \\
\hline & \multicolumn{6}{|c|}{ Panel II: window size $2 \%$} \\
\hline \multirow[t]{2}{*}{ Below population threshold (lag) } & $18.706^{* * * *}$ & -0.042 & -14.600 & 0.634 & -0.089 & -14.761 \\
\hline & $(5.940)$ & $(0.038)$ & (13.769) & $(5.935)$ & $(0.054)$ & $(16.761)$ \\
\hline \multirow[t]{3}{*}{ Above population threshold (lag) } & 4.355 & -0.001 & -19.284 & 0.923 & 0.012 & -5.606 \\
\hline & $(4.297)$ & $(0.037)$ & $(13.518)$ & $(6.417)$ & $(0.040)$ & $(13.223)$ \\
\hline & \multicolumn{6}{|c|}{ Panel III: window size $3 \%$} \\
\hline \multirow[t]{2}{*}{ Below population threshold (lag) } & $11.935^{* * *}$ & -0.009 & -14.345 & $-13.493^{*}$ & -0.041 & -13.012 \\
\hline & $(4.582)$ & $(0.036)$ & $(12.365)$ & $(6.874)$ & $(0.042)$ & $(14.677)$ \\
\hline \multirow[t]{3}{*}{ Above population threshold (lag) } & 2.258 & 0.003 & -19.416 & -9.923 & 0.060 & -1.900 \\
\hline & $(4.139)$ & $(0.035)$ & (12.997) & $(7.698)$ & $(0.042)$ & $(12.896)$ \\
\hline & \multicolumn{6}{|c|}{ Panel IV: window size $4 \%$} \\
\hline \multirow[t]{2}{*}{ Below population threshold (lag) } & $8.622^{* *}$ & 0.011 & -15.856 & -0.134 & -0.063 & -7.740 \\
\hline & $(4.354)$ & $(0.034)$ & (12.119) & $(7.991)$ & $(0.049)$ & $(15.557)$ \\
\hline \multirow[t]{3}{*}{ Above population threshold (lag) } & 0.275 & 0.027 & -12.759 & -5.186 & 0.033 & -5.794 \\
\hline & $(4.023)$ & $(0.049)$ & $(13.632)$ & $(5.014)$ & $(0.045)$ & $(15.150)$ \\
\hline & \multicolumn{6}{|c|}{ Panel V: window size 5\% } \\
\hline \multirow[t]{2}{*}{ Below population threshold (lag) } & $7.271 *$ & 0.035 & -11.201 & -2.945 & -0.061 & -11.270 \\
\hline & (4.013) & $(0.038)$ & $(12.508)$ & $(5.467)$ & $(0.041)$ & $(16.370)$ \\
\hline \multirow[t]{2}{*}{ Above population threshold (lag) } & 4.367 & 0.020 & -9.707 & -6.050 & 0.011 & -13.325 \\
\hline & $(4.586)$ & $(0.040)$ & $(12.629)$ & $(5.444)$ & $(0.050)$ & $(14.475)$ \\
\hline Controls & Yes & Yes & Yes & Yes & Yes & Yes \\
\hline Year FE & Yes & Yes & Yes & Yes & Yes & Yes \\
\hline Municipality FE & Yes & Yes & Yes & Yes & Yes & Yes \\
\hline Municipality time trend & Yes & Yes & Yes & Yes & Yes & Yes \\
\hline $\mathrm{N}$ & 6182 & 9961 & 9961 & 3804 & 6295 & 6295 \\
\hline
\end{tabular}

Note: The dependent variables are the absolute number of permits for apartment buildings ('Apartments'), the personal income tax rate and the property tax rate. The central independent variables are indicator variables for municipalities whose population size is below or above a relevant population threshold - with window sizes varying per panel in the table. The first three columns focus on municipalities where the mayor returns to power in a future legislative period, while the last three columns include only municipalities where the mayor does not return to power. All models include controls as indicated in the main text. Standard errors clustered at the municipality level reported in brackets: ${ }^{* * *}$ significant at $1 \%,{ }^{* *}$ at $5 \%$ and ${ }^{*}$ at $10 \%$.

local office-holders' strategic use of this revenue source may still be bolstered by the timing of these limited changes during the election cycle in municipalities nearing a population threshold (see Fig. 5).

\section{Concluding discussion}

This article evaluated whether, when and how-in the absence of outright manipulation-local governments try to achieve influence over population figures, such as to locate themselves on the desired side of legally imposed population thresholds leading to increases in the number and/or remuneration of local office-holders. Our main findings strongly suggest that local governments appear to strategically employ their fiscal and housing policies to attract more inhabitants. We also observe a highly suggestive pattern with respect to the timing of these fiscal and housing policy actions. As January 1 of an election year serves as a formal 'deadline' with respect to the population threshold, municipalities focus on this date and start granting additional apartment building permits and reduce tax rates at the onset of their legislative term. Moreover, we observe that strategic public policies appear predominantly implemented by mayors who (expect to) return to power in the next legislative period (and thus expect to benefit from crossing the population threshold). These findings are in line with the notion that strategic fiscal and housing policy decisions act as a key mechanism for influencing population levels when municipalities approach a population threshold with personal, economic implications for local office-holders. Clearly, further research should examine whether alternative mechanisms are also employed-such as the opening day-care facilities (to increase the municipality's attractiveness to young families), the construction of el- derly care centers, increasing the number of cultural activities, or the acceptance of more non-native migrants.

Our findings provide new evidence on rent-seeking behaviour in local public administrations (Gyourko and Tracy, 1989; Davis and Henderson, 2003; Ferraz and Finan, 2008, 2011b) by indicating that political agents respond to incentives related to personal, economic gain. Importantly, the exogenous nature of the imposed thresholds and our pre/post comparison of policy developments within the same municipality imply that our inferences are very likely to be causal in nature. As such, we contribute to a vast political economics literature on political agency and (self-)selection (Besley, 2005; Gagliarducci and Nannicini, 2013; Geys and Mause, 2016). In addition, given that the substantial room for interpretation when granting housing permits reflects in low local accountability in housing policies, our results are consistent with extensive scholarship observing a negative correlation between the level of political accountability and government corruption (Adsera et al., 2003; Lederman et al., 2005; Yan and Oum, 2014). ${ }^{17}$

Finally, our results can have important policy implications since local administrations may become less restrictive in granting building permits when important population thresholds are nearby. Consequently, a mechanism of control or accountability by higher-level governments might be required to prevent the acceptance of lower standards when population thresholds come within reach. Similarly, it is possible that

\footnotetext{
17 Treisman (2000) defines government corruption broadly as the misuse of public office for private use, which appears a close match to our main finding that local office-holders instigate public policies in part to target higher remuneration at exogenously imposed population thresholds.
} 
the quality and quantity of local services decrease due to the lower tax rates and the associated loss of fiscal revenues. Moreover, since local office-holders' incentives for influencing population developments change over the electoral cycle, more accountability appears needed particularly at the onset of the legislative term in which a relevant population threshold comes within reach. Overall, central administrations should be aware of the (perverse) incentives created by setting legally enshrined population thresholds. While such thresholds are often considered as a fair mechanism to distribute power and money, they can have unintended consequences.

\section{Supplementary materials}

Supplementary material associated with this article can be found, in the online version, at doi:10.1016/j.jue.2018.06.001.

\section{Appendix A}

Table A.1.

Table A.1

Summary statistics.

\begin{tabular}{|c|c|c|c|c|c|c|}
\hline Variable & Obs. & Mean & Std. Dev. & Min & Max & Time period \\
\hline $\begin{array}{l}\text { Population } \\
\text { threshold }\end{array}$ & 23,560 & 0.081 & 0.272 & 0 & 1 & 1977-2016 \\
\hline $\begin{array}{c}\text { Residential } \\
\text { buildings }\end{array}$ & 12,359 & 82.739 & 115.173 & 0 & 1849 & 1996-2016 \\
\hline Apartments & 12,359 & 41.950 & 91.855 & 0 & 1730 & 1996-2016 \\
\hline $\begin{array}{l}\text { One-family } \\
\text { residence }\end{array}$ & 12,359 & 40.788 & 38.857 & 0 & 811 & 1996-2016 \\
\hline $\begin{array}{l}\text { Non-residential } \\
\text { buildings }\end{array}$ & 12,359 & 8.604 & 10.160 & 0 & 150 & 1996-2016 \\
\hline Renovations & 12,359 & 45.166 & 60.861 & 0 & 1008 & 1996-2016 \\
\hline Property tax rate & 23,560 & 1592.587 & 712.524 & 0 & 3569 & 1977-2016 \\
\hline $\begin{array}{l}\text { Personal income } \\
\text { tax rate }\end{array}$ & 23,560 & 6.866 & 1.129 & 0 & 12 & 1977-2016 \\
\hline \multicolumn{7}{|l|}{ Controls } \\
\hline Population size & 23,560 & $17,454.2$ & $28,923.35$ & 80 & 530,826 & $1977-2016$ \\
\hline $\begin{array}{l}\text { Population } \\
\text { growth }\end{array}$ & 23,559 & 0.511 & 0.894 & -9.576 & 13.146 & $1977-2016$ \\
\hline Net migration & 21,204 & 0.391 & 0.739 & -7.000 & 7.128 & $1981-2016$ \\
\hline Income & 23,560 & 9.997 & 2.644 & 3.424 & 20.677 & 1977-2016 \\
\hline Unemployment & 21,774 & 3.547 & 1.780 & 0 & 15.831 & $1980-2016$ \\
\hline Elderly & 21,204 & 15.810 & 2.943 & 5.020 & 36.323 & $1981-2016$ \\
\hline Female & 21,202 & 50.741 & 1.060 & 43.529 & 57.738 & $1981-2016$ \\
\hline Flanders & 23,560 & 0.523 & 0.499 & 0 & 1 & $1977-2016$ \\
\hline $\begin{array}{l}\text { Net assessed } \\
\text { rental value }\end{array}$ & 20,615 & 482.324 & 214.457 & 171.015 & 3039.95 & $1982-2016$ \\
\hline $\begin{array}{l}\text { Public } \\
\text { expenditure }\end{array}$ & 18,657 & 821.818 & 296.071 & 37.394 & 4444.62 & 1985-2016 \\
\hline \multicolumn{7}{|l|}{ Mayors } \\
\hline Tenure & 2209 & 10.383 & 6.944 & 1 & 40 & 1977-2016 \\
\hline
\end{tabular}

Note: Population threshold is an indicator variable equal to 1 for municipalities whose population size is within $2 \%$ of a population threshold associated with higher mayoral wages and council size ( 0 otherwise). Residential buildings (Apartments, One-family residence, Non-residential buildings, Renovations) is the absolute number of building permits for residential properties (residential apartments, for one-family residences, for non-residential properties, renovations of residential buildings). The property and personal income tax rates are, respectively the surcharges raised on the regional property tax and the federal personal income tax. Population growth is the year-on-year change in the municipality's population size (in percent). Net Migration is the difference between the number of immigrants and emigrants as a share of the total population. Income is the average real per capita income in the municipality (in 1000EUR, base year is 2000). Unemployment, elderly and female are expressed as a share of the total municipal population. Flanders is an indicator variable equal to 1 for municipalities in Flanders ( 0 for municipalities in Brussels and Wallonia). Net assessed rental value is the tax base for the regional and local property tax (per capita, base year is 2000) and Public Expenditure is the total level of local government spending (per capita, base year is 2000). Tenure refers to the number of years a given mayor was in power over the period of observation.

\section{References}

Adsera, A., Boix, C., Payne, M., 2003. Are you being served? Political accountability and quality of government. J. Law Econ. Organ. 19 (2), 445-490.

Arnold, F., Freier, R., 2015. Signature requirements and citizen initiatives: Quasi-experimental evidence from Germany. Public Choice 162 (1), 43-56.

Besley, T., 2004. Paying politicians: theory and evidence. J. Eur. Econ. Assoc. 2 (2-3), $193-215$.

Besley, T., 2005. Political selection. J. Econ. Perspect. 19 (3), 43-60.

Bordignon, M., Cerniglia, F., Revelli, F., 2003. In search of yardstick competition: a spatial analysis of Italian municipality property tax setting. J. Urban Econ. 54 (2), 199-217.

Bordignon, M., Nannicini, T., Tabellini, G., 2016. Moderating political extremism: single round vs. runoff elections under plurality rule. Am. Econ. Rev. 106 (8), 2349-2370.

Brollo, F., Nannicini, T., Perotti, R., Tabellini, G., 2013. The political resource curse. Am. Econ. Rev. 103 (5), 1759-1796.

Buettner, T., 2001. Local business taxation and competition for capital: the choice of the tax rate. Reg. Sci. Urban. Econ. 31 (2-3), 215-245.

Buettner, T., 2003. Tax base effects and fiscal externalities of local capital taxation: evidence from a panel of German jurisdictions. J. Urban Econ. 54 (1), 110-128.

Card, D., Lee, D.S., Pei, Z., Weber, A., 2015. Inference on causal effects in a generalized regression kink design. Econometrica 83 (6), 2453-2483.

Cerina, F., Deidda, L.G., 2017. Rewards from public office and selection of politicians by parties. Eur. J. Polit. Econ. 47, 1-18.

Chanel, O., Delattre, L., Napoléone, C., 2014. Determinants of local public policies for farmland preservation and urban expansion: a French illustration. Land Econ. 90 (3), 411-433.

Chappell, H.W., Keech, W.R., 1986. Party differences in macroeconomic policies and outcomes. Am. Econ. Rev. 76 (2), 71-74.

Davis, J.C., Henderson, J.V., 2003. Evidence on the political economy of the urbanization process. J. Urban Econ. 53 (1), 98-125.

Duggan, M., Starc, A., Vabson, B., 2016. Who benefits when the government pays more? Pass-through in the medicare advantage program. J. Public Econ. 141, 50-67.

Eggers, A., 2015. Proportionality and turnout: evidence from French municipalities. Comparative Polit. Stud. 48 (2), 135-167.

Eggers, A., Freier, R., Grembi, V., Nannicini, T., 2018. Regression discontinuity designs based on population thresholds: pitfalls and solutions. Am. J. Polit. Sci. 62 (1), 210-229.

Ferraz, C., Finan, F., 2008. Exposing corrupt politicians: the effects of Brazil's publicly released audits on electoral outcomes. Q. J. Econ. 123 (2), 703-745.

Ferraz, C. and F. Finan (2011a). Motivating Politicians: the Impacts of Monetary Incentives on Quality and Performance. NBER Working Paper No. 14906.

Ferraz, C., Finan, F., 2011. Electoral accountability and corruption: evidence from the audits of local governments. Am. Econ. Rev. 101 (4), 1274-1311.

Foremny, D., Riedel, N., 2014. Business taxes and the electoral cycle. J. Public Econ. 115, 48-61.

Foremny, D., Jofre-Monseny, J., Solé-Ollé, A., 2017. 'Ghost citizens': using notches to identify manipulation of population-based grants. J. Public Econ. 154, 49-66.

Franzese Jr., R.J., 2002. Electoral and partisan cycles in economic policies and outcomes. Annu. Rev. Polit. Sci. 5 (1), 369-421.

Fujiwara, T., 2011. A regression discontinuity test of strategic voting and Duverger's law. Q. J. Polit. Sci. 6 (3-4), 197-233.

Gagliarducci, S., Nannicini, T., 2013. Do better paid politicians perform better? Disentangling incentives from selection. J. Eur. Econ. Assoc. 11 (2), 369-398.

Garmann, S., 2015. Elected or appointed? How the nomination scheme of the city manager influences the effects of government fragmentation. J. Urban Econ. 86, 26-42.

Geys, B., 2007. Government weakness and local public debt cycles: evidence from Flemish municipalities. Local Government Stud. 33 (2), 239-253.

Geys, B., Revelli, F., 2011. Economic and political foundations of local tax structures: an empirical investigation of Flemish municipalities' tax mix. Environ. Plann. C 29 (3), 410-427.

Geys, B., Osterloh, S., 2013. Politicians' opinions on rivals on the competition for businesses: an empirical analysis of reference points near a border. J. Reg. Sci. 53 (4), 583-606.

Geys, B., Mause, K., 2016. The limits of electoral control: evidence from final term politicians. Legislative Stud. Q. 41 (4), 873-898.

Glaeser, E.L., Ward, B.A., 2009. The causes and consequences of land use regulation: evidence from Greater Boston. J. Urban Econ. 65 (3), 265-278.

Gyourko, J., Tracy, J., 1989. On the political economy of land value capitalization and local public sector rent seeking in a Tiebout model. J. Urban Econ. 26 (2), 152-173.

Hahn, J., Todd, P., Van der Klaauw, W., 2001. Identification and estimation of treatment effects with a regression-discontinuity design. Econometrica 69 (1), 201-209.

Hettich, W., Winer, S., 1988. Economic and political foundations of tax structure. Am. Econ. Rev. 78, 701-712.

Hinnerich-Tyrefors, B., Pettersson-Lidbom, P., 2014. Democracy, redistribution, and political participation: evidence from Sweden 1919-1938. Econometrica 82 (3), 961-993.

Hopkins, D.J., 2011. Translating into votes: the electoral impact of Spanish-language ballots. Am. J. Polit. Sci. 55 (4), 814-830.

Imbens, G.W., Lemieux, T., 2008. Regression discontinuity designs: a guide to practice. J. Econometr. 142 (2), 615-635.

Klašnja, M., 2015. Corruption and the Incumbency Disadvantage: Theory and Evidence. J. Polit. 77 (4), 928-942.

Kok, N., Monkkonen, P., Quigley, J.M., 2014. Land use regulations and the value of land and housing: an intra-metropolitan analysis. J. Urban Econ. 81, 136-148.

Kotakorpi, K., Poutvaara, P., 2011. Pay for politicians and candidate selection: an empirical analysis. J. Public Econ. 95 (7-8), 877-885. 
Kubik, J., Moran, J., 2003. Lethal elections: gubernatorial politics and the timing of executions. J. Law Econ. 46 (1), 1-25.

Lederman, D., Loayza, N.V., Soares, R.R., 2005. Accountability and corruption: political institutions matter. Econ. Polit. 17 (1), 1-35.

Lee, D.S., Lemieux, T., 2010. Regression discontinuity designs in economics. J. Econ. Lit. 48 (2), 281-355.

Lijphart, A., 1999. Patterns of Democracy: Government Forms and Performance in 36 Countries. Yale University Press, New Haven.

Litschig, S., 2012. Are rules-based government programs shielded from special-interest politics? Evidence from revenue-sharing transfers in Brazil. J. Public Econ. 96, 1047-1060.

Mahieu, B., Geys, B., Heyndels, B., 2017. Fiscal fairness as a political argument. Kyklos $70(4), 622-640$.

McCrary, J., 2008. Manipulation of the running variable in the regression discontinuity design: a density test. J. Econometr. 142 (2), 698-714.

Messner, M., Polborn, M., 2004. Paying politicians. J. Public Econ. 88 (12), 24232445.

Mocetti, S., 2016. Dynasties in professions and the role of rents and regulation: evidence from Italian pharmacies. J. Public Econ. 113, 1-10.

Pellicer, M., Wegner, E., 2013. Electoral rules and clientelistic parties: a regression discontinuity approach. Q. J. Polit. Sci. 8 (4), 339-371.

Pettersson-Lidbom, P., 2012. Does the size of the legislature affect the size of government? Evidence from two natural experiments. J. Public Econ. 98 (3-4), 269-278.

Quigley, J.M., Raphael, S., Rosenthal, L.A., 2004. Local land-use controls and demographic outcomes in a booming economy. Urban Stud. 41 (2), 389-421.

Rohlfs, C., Sullivan, R., McNab, R., 2015. Can the president really affect economic growth? Presidential effort and the political business cycle. Econ. Inq. 53 (1), 240-257.
Rose, L.A., 1989. Urban land supply: natural and contrived restrictions. J. Urban Econ. 25 (3), 325-345.

Shi, M., Svensson, J., 2006. Political budget cycles: do they differ across countries and why. J. Public Econ. 90 (8), 1367-1389.

Solé-Ollé, A., Viladecans-Marsal, E., 2012. Lobbying, political competition, and local land supply: recent evidence from Spain. J. Public Econ. 96 (1), 10-19.

Taagepera, R., Shugart, W.F., 1989. Seats and Votes: The Effects and Determinants of Electoral Systems. Yale University Press, New Haven.

Treisman, D., 2000. The causes of corruption: a cross-national study. J. Public Econ. 76 (3), 399-457.

Tufte, E.R., 1980. Political Control of the Economy. Princeton University Press, Princeton.

Urquiola, M., Verhoogen, E., 2009. Class-size caps, sorting, and the regression-discontinuity design. Am. Econ. Rev. 99 (1), 179-215.

Vermeir, J., Heyndels, B., 2006. Tax policy and yardstick voting in Flemish municipal elections. Appl. Econ. 38 (19), 2285-2298.

Wieland, V., 2000. Monetary policy, parameter uncertainty and optimal learning. J. Monet. Econ. 46 (1), 199-228.

Wille, F., Deschouwer, K., 2012. Over Mensen en Macht. Coalitievorming in De Belgische Gemeenten. ASP Editions, Brussels.

Wilson, J.D., 1986. A theory of interregional tax competition. J. Urban Econ. 19 (3), 296-315.

Yan, J., Oum, T.H., 2014. The effect of government corruption on the efficiency of US commercial airports. J. Urban Econ. 80, 119-132.

Zodrow, G.R., Mieszkowski, P., 1986. Pigou, tiebout, property taxation and the underprovision of local public goods. J. Urban Econ. 19 (3), 356-370. 